\title{
University College, Cardiff: Exhibition of Nigerian Sculpture
}

AN exhibition of Nigerian traditional sculpture took place at University College, Cardiff, from 23 April to 17 May 1974. The works displayed belong to several public and private collections in Britain and also to the Nigerian High Commission. The exhibits were widely representative of the traditional styles of Nigerian sculpture, including examples of Benin ivories and bronze work, Yoruba sculptures, in metal and in wood, Ibo masks and many other items illustrating the art of various ethnic groups living in Nigeria.

\section{'The Matrilineal Peoples of Eastern Tanzania : Bibliographical Addenda}

Professor T. O. Berdelman writes: 'In Africa, xxxix (1969), 2, pp. $186-8$ I provided bibliographical corrigenda and addenda to my section of the Ethnographic Survey of Africa (East Central Africa, Part XVI). Since that time five years have elapsed and I have secured further items for this list, both in sources I previously failed to find and in the subsequent writings of other scholars who have taken an interest in this area. Since one of the major values in such surveys is the bibliographical information they provide, I should like to present further addenda to aid other researchers. In one case I provide more complete information on an item already cited.'

Anonymous. 1894. Nsachilo Nswamu kwa Mattayo kwa Nonga ya Kaguru. The Gospel of St. Matthew in the Kaguru Language. British and Foreign Bible Society, London.

1894. Zinyimbo ('Hymns for Public Worship' in Kimegi). Society for Promoting Christian Knowledge, London. (Probably by A. N. Wood with the help of D. Rees and D. Deekes; fairly reliable translations of traditional hymns into Chikaguru.)

- I909. Ussagara and Ugogo, pp. 67-76 in Handbooks for Workers. Outline Histories of C.M.S. Missions, i, Church Missionary Society, London. (Contains much useful though somewhat distorted information.)

Beidelman, T. O. 1968. A Case of Kaguru Oral History, Baessler-Archiv. xvi. 357-71.

1970a. Some Kaguru Folktales, Baessler-Archiv, xviii. 335-61.

- 1970b. Myth, Legend and Oral History: a Kaguru Traditional Text, Anthropos, 1xv. 74-97.

— 1971 a. Nine Kaguru Tales, Zeitschrift für Ethnologie, xcvi. 14-29.

- 1971b. Some Kaguru Notions about Incest and Other Sexual Prohibitions, pp. I81-201 in Kinship and Marriage (ed. Rodney Needham), A.S.A. Monograph No. I I, Tavistock, London. 19716. Kaguru Descent Groups, Anthropos, lxvi. 373-96.

- 1971d. The Kaguru: a Matrilineal People of East Africa. Holt-Rinehart-Winston, New York.

- I972a. The Filth of Incest: a Kaguru Text on Sexuality, Alimentation and Aggression, Cahiers d'études africaines, xxi. I64-73.

- 9726 . The Kaguru House, Anthropos, lxvii. I-I8.

- I 973 a. Dual Symbolic Classification among the Kaguru, pp. 128-66, in Right and Left (ed. Rodney Needham), University of Chicago Press, Chicago.

- 1973b. Three Kaguru Texts, Zeitschrift für Ethnologie, 98 : 90-101.

in press. Kaguru Texts : the Ambiguity of the Hare in Kaguru Folklore, Baessler-Archiv.

in press. The Bird Motif in Kaguru Folklore, Anthropos.

in press. Ambiguous Animals: Two Theriomorphic Metaphors in Kaguru Folklore, Africa.

Brain, James L. r969. Matrilineal Descent and Marital Stability: a Tanzanian Case, Journal of Asian and African Studies, iv. 2, pp. 1 22-3 I.

— 1971. Kingalu: a Myth of Origin from Eastern Tanzania, Anthropos, lxvi. 81 7-38.

- 1973a. Ancestors as Elders in Africa-Further Thoughts, Africa, xliii. 2, pp. 122-33.

- 1973b. Tales from Uluguru in Eastern Tanzania, Anthropos, Ixviii. I1 3-36.

Brokensha, David. 1971. Handeni Revisited, African Affairs, lxx. 279 (April), 159-68. (Some information on Zigula, Ngulu.)

Burgess, H. J. L. 1969 . The Health of Children in Kisarawe District, Tanzania. Tropical and Geographical Medicine (Haarlem), xxi, No. 1 : $39-46$. 
Cory, Hans n.d. History of Native Settlement. Chapt. 7. Ulugurus. Cory Papers 430/UCD. University of Dar es Salaam archives. (Not seen.)

Dammann, Ernst. 1956. Die religiöse Stellung des Häuptlings in ost- und südafrikanischen Bantustämmen, Paideuma, vi. I IO-I 7. (Some material on Bagamoyo in footnote; otherwise not useful, based on superficial library research.)

Dempwolff, Otto. 1916-17. Beiträge zur Kenntnis der Sprachen in Deutsch-Ostafrika, Zeitschrift für Kolonialsprachen, vii. I 34-92. (Uses some material on Zigula, taken from Meinhof.)

Fagg, William. 1965. Tribes and Forms in African Art. Methuen. London. (One Zaramo carving illustrated.)

Hadumbavhinu, R. L. I968. Waluguru na Desturi Zao, Tanzania Litho Ltd., Tanzania. (Not seen.)

Hartwig, Gerald W. 1969. The Role of Plastic Art in the Traditions in Tanzania, the Northeastern Region, Baessler-Archiv, xvii. 25-51. (Useful though somewhat superficial survey with many helpful illustrations of Zaramo, Kwere, Zigula, and Kami woodcarvings.)

Headland, Emily. 1890. Victoria Nyanza Mission, pp. 74-91 in Brief Sketches of C.M.S. Missions, Designed to Provide Material for Missionary Addresses. Pt. I, Nisbet, London. (Brief survey of C.M.S. in Ukaguru.)

Holý, Ladislav. 1967. The Art of Africa. Masks and Figures from Eastern and Southern Africa. Pau Hamlyn, London. (Some illustrations of Zaramo woodcarvings.)

Kieran, J. A. 1970. Abushiri and the Germans, pp. 157-201 in Hadith, ii, East African Publishing House, Nairobi. (Contains many useful references from missionary records on affairs in Uzaramo, Ungulu, Uluguru and Uzigua during the period of $188 \circ \mathrm{s}^{-9} \mathrm{\circ}$.)

Kisbey, W. H. I 906. Zigula-English and English-Zigula Dictionary, Society for Promoting Christian Knowledge, London.

Klamroth, M. 1912-13. Afrikanische Liebeslieder. b. Ein Dzalamo-Lied, Zeitschrift für Kolonialsprachen, iii. 247.

Krelle, H. I9r3. Eine Sage der Saramo über Ursprung des Todes, Der Njassa-Bote, Berlin, $59 \mathrm{ff}$. (Not seen.)

1929. Tuheri, Werden und Wachsen eines Saramo Christian, Berlin. (Not seen.)

Lips, Julius. 1966. The Savage Hits Back (Ist ed. 1937), University Books, Hyde Park, N.Y. (A few Zaramo woodcarvings illustrated.)

Mawinza, Joseph. 1963 . The Human Soul: Life and Soul-Concept in an East African Mentality based on the Luguru. A Dissertation presented to the Faculty of Philosophy of the Pontifical Urbanian University. Pontificia Universitas Urbaniana, Rome. (Not seen.)

- 1969. Reverence for Ancestors in Tanzania with reference to the Luguru and other Bantu Tribes, Cahiers des religions africaines, iv. 239-48. (Not very useful.)

Mluanda, M. I971. Ancestral Cult among the Luguru, Review of Ethnology (Vienna), iii. 9, pp. 65-8. (Not seen.)

Page-Jones, F. H. and Soper, J. R. 1955. A Departmental Enquiry into the Disturbed Situation in the Uluguru Chiefdom. Cory Papers $36_{4} / \mathrm{UCD}$, University of Dar es Salaam archives. (Not seen.)

Price,R. 1876. Report of the Rev. R. Price of His Visit to Zanzibar and the Coast of Eastern Africa. London Missionary Society, London. (Not very useful, but one of the first reports from the area.)

Richelmann, G. I 892. Meine Erlebnisse in der Wissmann-Truppe. Creutz. Magdeburg. (Recollections by a former district officer at Bagamoyo; much on Bushiri's rebellion; little on ethnography, but useful on early political affairs, especially for Bagamoyo, Pangani, Tanga, and Uzaramo.)

Ricklin, L. A. 1 880. La Mission catholique du Zanguebar: travaux et voyage du R. P. Horner. Gaume, Paris.

Sicard, S. von 1970. The Lutheran Church on the Coast of Tanzania 1884-1914 with special reference to the Evangelical Lutheran Church in Tanzania, Synod of Uzaramo-Uluguru, xii, Studia Missionalia Upsaliensia, Gleerup, Lund. (Much useful information on early colonial history of Uzaramo and Uluguru.)

Steere, Edward 1869. Short Specimens of the vocabulary of three unpublished African languages (Ginda, Zaramo, and Angazidia). Charles Cull, London.

- 1880. $A W$ alk in the Zaramo Country, U.M.C.A., Occasional Papers. London. (Not seen.)

Stuhlmann, F. 1896. Die Höhenmessungen Dr. Stuhlmanns während drei Reisen in dem Jahre I894 in Usaramo, Ukami, Uluguru u.s. w. und von Premier-Lieutnant Schlobach in den 
Jahren $1894 / 95$ in den gleichen Gebieten, Mittheilungen von Forschungs reisenden und Gelehrten aus den deutschen Schutzgebieten, ix. 247-9. (Has useful map.)

— 1916-17. Wortlisten zentralafrikanischen Stämme, Zeitschrift für Kolonialsprachen, vii. 257-308. (Uses some material from Zaramo, pp. 303-4.)

Swantz, Lloyd. 1970. The Zaramo of Dar es Salaam, Tanzania Notes and Records, 1xxi. I 57-64.

n.d. The Zaramo of Tanzania. An ethnographic survey. Nordic Tanganyika Project, Dar es Salaam. (A useful survey.)

Swantz, Marja-Liisa. 1970. Ritual and Symbol in Traditional Zaramo Society with special reference to women. xvi, Studia Missionalia Upsaliensia, Gleerup, Lund.

Temple, P. 1970. Conservation Policies in the Uluguru Mountains: a Study of Purpose, Design, Impact and Result, with Particular Reference to Mgeta Area, Geog. Ann. liv. (Not seen.)

Thomas, I. D. 1969. Some Notes on Population and Land Use in the More Densely Populated Parts of the Uluguru Mountains of the Morogoro District. University College, Bureau of Resource Assessment and Land Use Planning, Dat es Salaam. (Not seen.)

Westgate, T. B. R. I91 3a. A New Era, Church Missionary Gleaner, xl. 56.

- I9I $3 b$. Sacred Rainstones, Church Missionary Gleaner, xl. I 54-5. (Both about Ukaguru.)

\section{Addendum}

1972 Ingle, C. R. From Village to State in Tanzania. Cornell Univ. Press, Ithaca. (material on Zigula.)

\section{NOTES FOR CONTRIBUTORS TO AFRICA}

Contributions should be addressed to the Editor. Articles should not exceed 8,000 words, including footnotes and references. Longer papers can be accepted in exceptional circumstances if a subsidy can be provided to meet the cost of printing additional pages.

Articles should be typed in double spacing, on one side of the paper only, with ample margins to allow for editorial marking. Clean copy ready for printing should be provided. Authors are advised to keep a copy of their texts as the return cannot be guaranteed. Words in African languages should be underlined and special characters kept to a minimum. Footnotes may be placed at the bottom of the page on which they occur or all together at the end. Bibliographical references should be cited only briefly (i.e. author and date) in the text where possible, and an alphabetical list of references given in full at the end of the article. Where appropriate the text should be divided by suitable headings and sub-headings. Tables outside the text should be typed on separate pages, numbered consecutively and given headings. Maps and other line drawings should be submitted in final form (except for size) on good quality paper.

Contributors are asked to provide a summary of their articles of 290-300 words for translation into French or English.

Page proofs are submitted to authors but only essential corrections can be accepted; additional matter cannot be inserted at proof stage. The Editor reserves the right to make any corrections or alterations he may deem necessary.

Contributors receive $2 s$ free offprints of their articles; extra copies can be supplied at cost price on request, if ordered before publication. 